\title{
Constituents from the leaves of Crataegus davisii Browicz
}

\author{
Ulaş Sözer ${ }^{1}$, Ali A. Dönmez ${ }^{2}$, Ali H. Meriçli ${ }^{* 1}$ \\ ${ }^{1}$ Istanbul University, Faculty of Pharmacy, Department of \\ Pharmacognosy, Beyazit, 34116 Istanbul-Turkey \\ ${ }^{2}$ Hacettepe University, Faculty of Science, Department of Biology, \\ Beytepe, 06532 Ankara-Turkey
}

\section{Abstract}

From the leaves of Crataegus davisii five flavonoids ( hyperoside, vitexin 2"rhamnoside, vitexin 4'-rhamnoside, rutin, quercetin ) together with chlorogenic acid and crataequinone $\mathrm{B}$ were isolated.

The flavonoid content of the leaves was determined according to DAB 10 and found as $1.09 \%$. The $\mathrm{IC}_{50}$ value was found as $1.57 \mathrm{mg} / \mathrm{ml}$ at antioxidant activity determination with DPPH method.

\section{Keywords}

Crataegus davisii, Rosaceae, Flavonoids, Antioxidant activity

\section{Introduction}

Crataegus species, known as "Hawthorn", are especially used for mild heart diseases. Flavonoids are the main constituents responsible for the biological activities. The most important feature of Crataegus extracts is their positive inotropic effect. They increase the activation of the heart muscle cells, provide them a well feeding, regulate the blood flow and are coronary dilatators [1, 2].

The genus Crataegus is represented by 21 species in Turkey. C.davisii is an endemic plant, which is botanically very close to C. pentagyna [3].

In continuation of our investigations on Turkish Crataegus species [4-9] we now investigated the constituents from the leaves of $C$. davisii. 


\section{Results and Discussion}

From the leaves of Crataegus davisii five flavonoids hyperoside, vitexin 2"rhamnoside, vitexin 4'-rhamnoside, rutin, quercetin (Fig. 1) together with chlorogenic acid and crataequinone B (Fig. 1) were isolated. The main flavonoids are hyperoside and vitexin 4'-rhamnoside.

The flavonoid content of the leaves was determined according to DAB 10 and found as $1.09 \%$. The $\mathrm{IC}_{50}$ value was found as $1.57 \mathrm{mg} / \mathrm{ml}$ at antioxidant activity determination with DPPH method.

The leaves of some Turkish Crataegus species are rich in flavonoids [4,7], but the leaves of $C$.davisii are quiet poor and considering the results of the study, it is not probable that $C$. davisii can be recommended for medicinal use.

\section{Experimental}

\section{Plant material}

The leaves of Crataegus davisii Browicz (Rosaceae) were collected from Hakkari, between Semdinli and Yuksekova, Turkey, at an altitude of $1600 \mathrm{~m}$ in October 2001 and identified in our department (A. A. D.). Voucher specimens have been deposited in the Herbarium of the Faculty of Science, Hacettepe University (AAD 10326).

\section{Instruments}

UV: Jasco 530 V, IR: Perkin Elmer 1600 Series FTIR, NMR: Varian INOVA $500 \mathrm{MHz}$.

\section{Extraction and isolation of the constituents}

The dried and powdered leaves of Crategus davisii $(500 \mathrm{~g}$ ) were extracted in a Soxhlet apparatus first with petroleum ether and then with ethanol. The PE extract was concentrated and extracted with $60 \% \mathrm{EtOH}$. The aqueous extract was concentrated and extracted with $\mathrm{CHCl}_{3}$ (Extract A). The EtOH extract was concentrated and extracted with toluene, $\mathrm{CHCl}_{3}$ (Extract $\mathrm{B}$ ) and ethyl acetate (Extract C) successively. 
Extract $A$ was chromatographed first by vacuum liquid chromatography (VLC) on silica gel with PE: $\mathrm{CHCl}_{3}: \mathrm{MeOH}$ mixtures. Fractions $11-12\left(\mathrm{CHCl}_{3}: \mathrm{MeOH}\right.$ $80: 20,180 \mathrm{mg}$ ) were then chromatographed on a chromatotron (silica gel) again with PE: $\mathrm{CHCl}_{3}: \mathrm{MeOH}$ mixtures and from fraction $42\left(\mathrm{PE}: \mathrm{CHCl}_{3}, 20: 80\right) 2 \mathrm{mg}$ crataequinone $B$ were obtained.

Extract $\mathrm{B}$ was chromatographed first by VLC on silica gel with toluene:acetone:MeOH mixtures. Fractions 6-8 (toluene:acetone, 75:25 to 60:40, $210 \mathrm{mg}$ ) were then chromatographed on a chromatotron (silica gel) again with toluene:acetone:MeOH mixtures and from fractions 40-48 (toluene:acetone $30: 70$ to $10: 90$ ) $4 \mathrm{mg}$ quercetin were obtained.

Extract $\mathrm{C}$ was chromatographed first on a silica gel column with toluene:EtOH mixtures. Main fractions 153-304 (toluene:EtOH, 50:50, $765 \mathrm{mg}$ ) were then chromatographed on a chromatotron (silica gel) with toluene: $\mathrm{CHCl}_{3}$ : EtOH mixtures and from fractions $24-32\left(\mathrm{CHCl}_{3}: \mathrm{EtOH}, 50: 50\right.$ to $\left.30: 70,351 \mathrm{mg}\right)$ $11 \mathrm{mg}$ hyperoside, $10 \mathrm{mg}$ vitexin 4'-rhamnoside and $7 \mathrm{mg}$ rutin were obtained using preparative PC (acetic acid: $\mathrm{H}_{2} \mathrm{O}, 15: 85$ ). Main fractions 305-380 (EtOH, $210 \mathrm{mg}$ ) were chromatographed on a polyamide column with $\mathrm{H}_{2} \mathrm{O}: \mathrm{EtOH}$ mixtures and from fractions 77-133 $\left(\mathrm{H}_{2} \mathrm{O}: \mathrm{EtOH}, 80: 20,52 \mathrm{mg}\right) 5 \mathrm{mg}$ vitexin 2"-rhamnoside and from fractions 268-393 ( $\mathrm{H}_{2} \mathrm{O}: \mathrm{EtOH}, 40: 60$ to 10:90, $\left.295 \mathrm{mg}\right) 6 \mathrm{mg}$ chlorogenic acid were obtained.

The structures of the isolated compounds were determined by comparison with authentic samples and with the interpretation of their UV, IR and in case of crataequinone with ${ }^{1} \mathrm{H}$ NMR spectra [10]. Flavone O- and C-glucosides were subjected to acid and $\mathrm{FeCl}_{3}$ hydrolysis respectively.

The flavonoid content was determined according to DAB 10 [11], the antioxidant activity was determined with DPPH method in comparison with ascorbic acid [12].

\section{Acknowledgement}

This work was supported by the Istanbul University Research Fund (T-314/03112003). 
<smiles>CC(=O)COc1c(-c2ccc(O)c(O)c2)oc2cc(O)cc(O)c2c1=O</smiles>

Hyperoside<smiles></smiles>

Vitexin 2"-rhamnoside<smiles>CCCCOc1ccc(-c2cc(=O)c3c(O)cc(O)c(Cl)c3o2)cc1</smiles>

Vitexin 4'-rhamnoside<smiles>O=C(/C=C/c1ccc(O)c(O)c1)OC1CC(O)(C(=O)O)CC(O)C1O</smiles>

Chlorogenic acid<smiles>COc1oc2c(c1OC)C(=O)C(=O)c1cccc(O)c1-2</smiles>

Crataequinone B<smiles>CCOOCCOc1c(-c2ccc(O)c(O)c2)oc2cc(O)cc(O)c2c1=O</smiles>

Rutin<smiles>O=c1c(O)c(-c2ccc(O)c(O)c2)oc2cc(O)cc(O)c12</smiles>

Quercetin

Fig. 1: Structures of the isolated compounds from the leaves of Crategus davisii 


\section{References}

[1] Ammon H P T, Haendel M.

Crataegus, Toxikologie und Pharmakologie, Teil II: Pharmakodynamik.

Planta Med. 1981;43:209-39.

[2] Kaul R.

Der Weissdorn.

Stuttgart:Wissenschaftliche Verlagsgesellschaft mbH, 1998:35-154.

[3] Dönmez A A.

The genus Crataegus L. ( Rosaceae ) with special reference to Hybridisation and biodiversity in Turkey.

Turk. J. Bot. 2004;28:29-37.

[4] Meriçli A H, Ergezen K.

Flavonoids of Crataegus tanacetifolia ( Lam. ) Pers. ( Rosaceae ) an endemic species from Turkey.

Sci. Pharm. 1994;62:277-81.

[5] Melikoglu G, Meriçli F, Meriçli A H.

Flavonoids of Crataegus orientalis.

Boll. Chim. Farmaceutico. 1999;138:351-2.

[6] Melikoglu G, Meriçli A H.

Flavonoids of Crataegus stevenii.

Pharmazie. 2000;55:326-7.

[7] Melikoglu G, Bitiş L, Mericli A H.

Flavonoids of Crataegus microphylla.

Nat. Prod. Res. 2004;18:211-3.

[8] Birman H, Salmayenli N, Melikoglu G, Meriçli A H.

effect of Crataegus tanacetifolia extract on total bady ion concentration in normal rats.

Acta Pharm. Turcica. 2003;45:215-9.

[9] Çelebi-Koçyildiz Z, Birman H, Olgaç G, Akgün-Dar K, Melikoglu G, Meriçli A H.

Crataegus tanacetifolia leaf extract prevents L-NAME-induced hypertension in rats: a morphological study.

Phytother. Res. 2006;20:66-70. 
[10] Min B S, Huong H, Kim J, Jun H, Na M, Nam N, Lee H, Bae K, Kang S. Furo-1,2-naphtoquinones from Crataegus pinnatifida with ICAM-1 expression inhibition activity.

Planta Med. 2004;70:1166-9.

[11] DAB 10, Band 3.

Monographien, Weissdornblätter mit Blüten.

Stuttgart:Deutscher Apotheker Verlag. 1997.

[12] Suja KP, Jayalekshmy A, Arumughan C.

Antioxidant activity of sesame cake extract.

Food Chemistry 2005; 91: 213-219 